\title{
Use of innovative and advanced computer simulations of chemical speciation of heavy metals in soils and other environmental samples
}

Abstract: The article presents several aspects of computer simulations and models of heavy metals speciation in environmental samples. The methods can be effectively used in environmental sciences, soil science, and assessment of mobility and bioavailability of heavy metals in contaminated areas. The article presents all of the methods based on examples, and with interpretation of results. The effect depends on the reliability of data used in models. The results are essential for predicting the fate and behaviour of elements in the environment, and can also be used to develop solubility curves.

Key words: chemical speciation, computer simulation, models, metals

\section{INTRODUCTION}

Modelling methods have been applied in the assessment of environmental risk (Risk Assessment-RA) related to heavy metals and a number of substances and chemical preparations or crop protection chemicals for years. Models are also used for the Life Cycle Assessment (LCA) of many products (Pizzol et al. 2012). Traditional methods of sequential analysis involve the consecutive extraction of the same sample with selectively working reagents. This permits the identification and quantitative determination of the fraction of a given element. The currently used methods of sequential analysis are subject to numerous modifications, or the approach of so-called hybrid sequential analysis is applied. It involves the separation and determination of the content of the analyte, or the entire group of analytes in an environmental sample with the application of techniques such as gas and liquid chromatography or capillary electrophoresis. Advanced software with varied applications in the analysis of environmental samples has been globally used in recent years.

The objective of the article was to present selected advanced speciation analysis computer software (among others MINEQL, SOILCHEM, MINTEQA2, PHREEQC-2, etc.) particularly used for speciation of heavy metals in environmental samples, as well as to present its practical application in scientific studies. The replacement of traditional analytical me- thods with digital methods has a significant economic and environmental aspect. The application of models also enriches the already existing studies with additional information necessary for environmental risk assessment.

\section{METODS AND MODELS USED IN SOIL AND ENVIRONMENTAL SCIENCES}

According to the definition by IUPAC, speciation studies involve the identification and/or measurement of the content of one or more chemical forms of a given metal in a sample. Speciation is defined as the determination of specific forms of occurrence of a given element (Rogan et al. 2008; Rastmanesh et al. 2010; Rutkowska et al. 2013). The determination of the current and potential bioavailability or mobility requires the distinguishing and determination of forms or fractions of heavy metals. This is particularly important in the case of contaminated soils. Predicting the behaviour of elements in the environment is based on the understanding of processes occurring in soils, and the knowledge of the existing relations. Therefore, in addition to the geochemical properties of a given element, the examination and analysis of fractions of selected elements should also consider the basic properties of soils (reaction, grain structure, content of organic carbon, content of carbonates, and structure and volume of the sorption complex), the type of soils, and binding of heavy metals with soil components 
such as: organic matter, iron and manganese oxides, carbonates, phosphates, sulphates, and primary and secondary minerals.

The application of computer software in the speciation analysis of heavy metals in soil, water, or sediment samples aims at the development of models describing phenomena occurring in the environment by means of statistical, mathematical, or graphic methods. Such models are developed based on actual or simplified data which must be defined in detail, and described in controlled conditions. Models most commonly applied in soil sciences are the Langmuir and Freundlich models, used for the analysis of the phenomenon of sorption of contaminants in soils (Kowalkowski and Buszewski 1999; Lumsdon and Evans 2002; Vithanage et al. 2013). The majority of speciation methods are based on the assumption of thermodynamic balance between phases. The models additionally apply electrostatic forces affecting binding of metal ions in soils. The models can describe phenomena such as among others the intake of nutrients by plants, the accumulation of heavy metals and radionuclides in soils and sediments, transport of pollutants with the colloidal fraction of soils and sediments (e.g. surface runoff), or development of complex compounds with fulvic acids (Lumsdon and Evans 2000; Zachara et al. 1989; Davis and Kent 1990; Sposito et al. 1983, Sposito and Coves 1988; Goldberg et al. 2005). According to the division by Bonazountas (1986), models describing soil quality are composed of two parts:

- the deterministic part, including the characteristic (module) of the studied medium, and involving the simulation of chemical reactions responsible for specific chemical composition of the analysed sample, considering e.g. hydrological cycles, cycle of elements in systems, e.g. soil-soil solution-water, plants;

- the stochastic part, aimed at the prediction of routes of exposure (transport, mobility) of the studied compounds/metals/pollutants, soil transformations, or the degree of contamination and quality e.g. of soils occurring in the study area.

Research regarding computer speciation of elements in environmental samples commenced in the 1960's. One of the first programs proposed in the scope was COMICS (Perrin and Sayce 1967). In the following years, a number of new programs were developed, such as e.g. REDEQL (Morel and Morgan 1972), SIAS (Fardy and Sylva 1978), TITRATOR (Cabaniss 1987), SOILCHEM, and its modification - GEOCHEM (Mattigod and Sposito 1979; Sposito and Coves 1988). Since the development of the first computer software for heavy metal speciation analysis, a number of new models and programs appeared, permitting the description of phenomena occurring in the soil, such as mobility of heavy metals in soils, and their interactions with iron oxides or organic compounds. An example of such software is MINTEQA2, a geochemical equilibrium speciation model used for the calculation of the equilibrium composition of solutions in laboratory or field conditions. The program includes a complex database permitting defining appropriate data for the model. The model also applies data predefined by the program, such as: the content of $\mathrm{Na}^{+}$ions or $\mathrm{H}_{4} \mathrm{SiO}_{4}{ }^{0}$ complexes (Allison et al. 1999). The model includes more than 1000 values of ion or particle forms which can develop heavy metals. Similarly as traditional methods applied in soil and environmental sciences, programs and models for speciation analysis are continuously modified. For example, MINTEQA2 version 4.0 has a Gauss model competitive towards the previous versions of the model, permitting the description of the phenomenon of complexation of heavy metals with organic matter (Allison et al. 1999). Speciation calculations can be performed under the condition of the determination of not only the analytical concentrations of heavy metals, but also $\mathrm{pH}$, temperature, and redox potential.

$\mathrm{pH}$ and temperature values are used for the calculation of the ionic strength of a soil solution, ionic activity coefficients, and solution components (Winid 2013). Then, according to Winid (2013), molar activities and concentrations of complex compounds are calculated. This permits the determination of forms of elements and their percent contribution and activity in the studied medium (water, soil solution). The base values for calculations used in computer programs are obtained from data bases. Like in any model, the selection of the relevant data base has the decisive influence of the final results. It should be remembered that output data selected for the model must be credible and coherent. Data bases of the existing programs also differ from one another. This should be considered in the selection of the appropriate speciation analysis software. It should be emphasised that one computer program can apply a number of models (for example combined: diffusion layer model, triple layer model, etc.), simulating the complex conditions of the environmental conditions. Models included in a computer program develop the so-called "geochemical speciation code" (Kowalkowski and Buszewski 1999; Falc 1991). Modern models can be used for predicting the fate and behaviour of elements in soils, waters, or sediments based on the occurring forms and their binding with organic matter, iron and manganese oxides and hydroxides, and clay minerals (Goldberg et al. 2005). The table below presents selected programs and models with their application (Table). 
TABLE. Selected computer programs and models used in the speciation analysis of environmental samples

\begin{tabular}{|c|c|c|}
\hline $\begin{array}{l}\text { Program } \\
\text { Program }\end{array}$ & $\begin{array}{l}\text { Przykładowe zastosowanie programów i modeli } \\
\text { Example use of speciation programs and models }\end{array}$ & $\begin{array}{l}\text { Źródło } \\
\text { References }\end{array}$ \\
\hline SOILCHEM & $\begin{array}{l}\text { Speciation of heavy metals in soils, complexation reactions (among others heavy } \\
\text { metals-fulvic acids), determination of the chemical equilibrium of soil solutions }\end{array}$ & $\begin{array}{l}\text { Sposito and Coves } \\
1988\end{array}$ \\
\hline GECOHEM & Speciation of heavy metals in soil solutions and other natural water systems & $\begin{array}{l}\text { Sposito and Mattigod } \\
1980\end{array}$ \\
\hline PHREEQE & Reactions of complexation with organic matter & $\begin{array}{l}\text { Falc } 1991 \\
\text { Crawford } 1996\end{array}$ \\
\hline HYDRAQL & $\begin{array}{l}\text { Determination of chemical equilibrium in water samples, complexation and adsorption } \\
\text { of ions at phase boundaries }\end{array}$ & Papelis et al. 1988 \\
\hline $\begin{array}{l}\text { MINTEQA2/ } \\
\text { PRODEFA2 }\end{array}$ & Speciation of heavy metals in soils, sediments (geochemical modelling) & $\begin{array}{l}\text { Allison et al. } 1999 \\
\text { EPA } 1999\end{array}$ \\
\hline ECOSAT & $\begin{array}{l}\text { Speciation of all elements in soils and waters (determination of among others gas, } \\
\text { complex, mineral, and organic forms) } \\
\text { Mobility of elements in the water-soil system }\end{array}$ & Keizer 1991 \\
\hline DDLM & $\begin{array}{l}\text { Models of complexation of heavy metals with organic matter and hydrated iron } \\
\text { hydroxides }\end{array}$ & $\begin{array}{l}\text { Dzombak and Morel, } \\
1990 \\
\text { Vithanage et al. } 2013\end{array}$ \\
\hline $\begin{array}{l}\text { TRANQL } \\
\text { (MICROQL, } \\
\text { ISOQUAD) }\end{array}$ & $\begin{array}{l}\text { Simulation of transport of ions/forms, e.g. Cd in groundwaters, and surface } \\
\text { complexation reactions }\end{array}$ & Cedeberg et al. 1985 \\
\hline UNSATCHEM & Simulation of transport of ions, assessment of the mobility of heavy metals in soils & Goldberg et al. 2005 \\
\hline ECCLES & Models of speciation of heavy metals in biological samples & Wesley et al. 2012 \\
\hline GEOSURF & Models of adsorption on mineral surfaces & $\begin{array}{l}\text { Sahai and Sverjensky } \\
1998\end{array}$ \\
\hline
\end{tabular}

\section{PRACTICAL USE OF COMPUTER PROGRAMS FOR SPECIATION OF ELEMENTS IN ENVIRONMENTAL SAMPLES}

The application of computer programs and modelling in environmental sciences permits the assessment of the quality of the environment. Consequently, it also permits the assessment of the risk of exposure of people resulting from the toxic or cancerogenic properties of heavy metals. It can constitute an important element of the decision making process and adopting of strategies in the case of the existing threat to human health and life resulting from e.g. emission, or release of heavy metals to the environment. Five basic categories of application of models in environmental sciences are generally distinguished:

1. Emission models are used for the estimation of the release of pollutants to the environment (washing out of waste dumps, air pollution);

2. Fate models are used for the estimation of predicted concentrations/contents of pollutants in the studied medium (e.g. fate and behaviour of heavy metals in soils, groundwaters, or surface waters);
3. Exposure models are used for the analysis of routes of exposure, e.g. by inhalation, and the determination of predicted environmental concentrations;

4. Risk models are also known as models of determination of the dose-response relationships (e.g. in the assessment of environmental risk resulting from the application of crop protection chemicals), used in the human health risk assessment by the extrapolation of data from toxicity and ecotoxicity tests for animals;

5. Cost/efficiency models are used for health risk reduction by the application of corrective measures (e.g. phytoremediation and mycoremediation of soils) (Bonazountas 1986; Jóźwiak 2013).

The following diagram presents a simplified procedure of selection of computer programs and mathematical models for speciation analyses of heavy metals (Figure).

The following is a review of practical applications of speciation methods involving the use of models and computer programs in environmental samples. Goldberg et al. (2005) studied the mobility and adsorption of boron in soils with varying grain structure. The assessment of the mobility and binding 


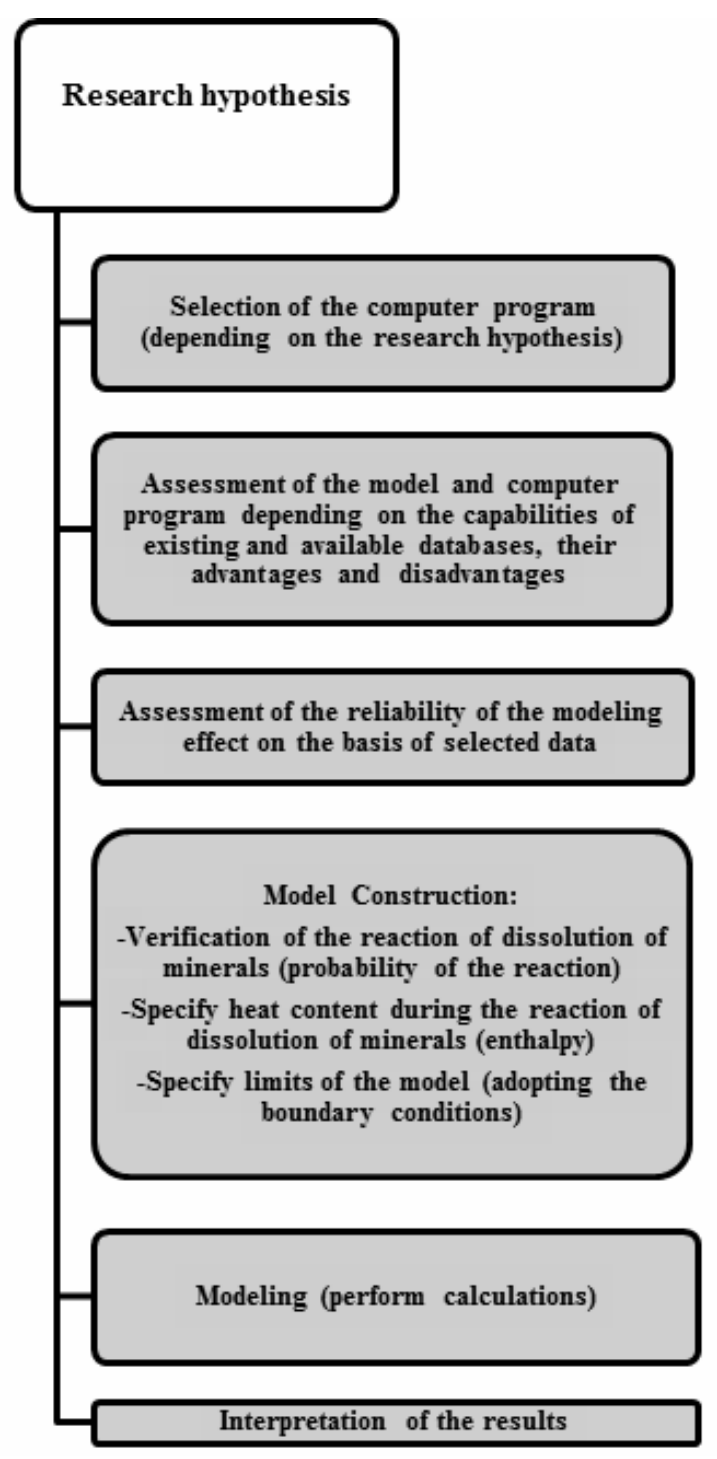

FIGURE. Procedure for the selection of computer software and models for speciation of heavy metals in environmental samples (after Jóźwiak 2013)

of the element in the studied soils was performed with the application of FITEQL version 3.2 and among others model UNSATCHEM. The application of the computer program allowed the authors to evidence that the adsorption of boron increased along with an increase in $\mathrm{pH}$, reaching the maximum at $\mathrm{pH}=9$. The analysis of the adsorption of the element was possible due to the determination of the constants of the surface complexation equilibrium. The phenomenon of copper adsorption on mineral surfaces was observed by Sahai and Sverjensky (1998) with the application of the GEOSURF software. The program was developed based on programs such as MINEQL, MICROQL, or HYDRAQL. According to the authors, the program permits effective analyses of samples with vary diverse chemical compositions, and in the case of redox reactions and surface complexation reactions, problematic in traditional methods.

Smal (1999) analysed among others the effect of acidification on the distribution of ionic forms in soil solutions of light soils with the application of the SOILCHEM software. The program permitted the presentation of the speciation of divalent and trivalent elements, whereas the main forms of particular elements were presented, e.g. iron-sulphate complexes $\left(\mathrm{Fe}-\mathrm{SO}_{4}\right)$ with no consideration of other forms (e.g. $\left.\mathrm{FeSO}_{4+} \mathrm{Fe}\left(\mathrm{SO}_{4+}\right)_{2}^{-}\right)$. The application of the SOILCHEM software permitted the presentation of the detailed percent distribution in soil solutions in soil profiles of elements such as: lead(II), cadmium, copper(II), zinc, iron(III), aluminium, manganese(II), magnesium, and calcium (Smal 1999).

The speciation of cadmium and copper with the application of the Visual MINTEQ software was performed by Rathnayake et al. (2013). The authors analysed the effect of the content of $\mathrm{Cu}$ and $\mathrm{Cd}$ on the growth and development of bacteria in culture media. The application of the MINTEQ software permitted the determination of the chemical composition of the culture media, and the assessment of the toxic effect of heavy metals on bacteria. The effect of soil properties on the speciation of copper in a soil solution was also analysed (Rutkowska et al. 2013) with the application of the MINTEQA2 software. Based on the results, it was evidenced that copper mainly occurred in the soil solution in a form bound to humic acids. The obtained results were the most affected by the soils' reaction. In soils with acidic reaction, the content of free copper ions, complexes with organic matter, and forms bound with carbonates and sulphates, as well as forms of copper bound to hydroxyls decreased. The degree of contamination and grain structure of soils did not determine the percent contribution of particular copper forms in the soil solution. The authors also evidenced that soils with higher contents of organic carbon contained lower amounts of free copper ions with a simultaneous increase in the organic complexes of the element (Rutkowska et al. 2013).

Mohammed (2012) used the MINTEQ software for modelling zinc sorption in soils with varied $\mathrm{pH}$. The model was determined to be appropriate for the prediction of the fate and behaviour of zinc in the soil environment, and particularly in samples in which the experimental analyses had not been possible before. The model can be applied for predicting the chemical composition of not only soils, but also wastes or run-offs from potentially hazardous waste dumps. Sorption of heavy metal ions in water solutions on sorbents modified with chelating agents can be described mathematically with the application of 
the MINEQL (Visual MINTEQ) software. The program permits predicting the mechanisms of removal of metals e.g. from soils or waters by means of modified sorbents (Ołpiński et al. 2011).

Zhang et al. (2008) used the MINTEQ software for the assessment of washing out of heavy metals contained in ashes from a solid waste combustion plant. The model applied a simulation of mechanisms of dissolution and precipitation of $\mathrm{Pb}, \mathrm{Cd}, \mathrm{Zn}$, and $\mathrm{Ni}$. It was determined that washing out of all of the studied heavy metals depends on the $\mathrm{pH}$ value. Based on the modelling results, however, differences in the behaviour of the studied elements were observed. The mobility of $\mathrm{Pb}$ and $\mathrm{Cd}$ particularly depends on the release/precipitation reaction, and the mobility of $\mathrm{Zn}$ and $\mathrm{Ni}$ on the mechanisms of surface adsorption at a strictly defined range of $\mathrm{pH}$ values (Zhang et al. 2008).

Erten-Unal and Wixon (1999) used the MINTEQ software for the speciation of zinc and lead in water and mining sewage samples. It was evidenced that zinc mainly occurred in carbonate forms (70-80\%), and lead in hydroxide forms. Binding of the elements with $\mathrm{OH}^{-}, \mathrm{HCO}^{-}$, and $\mathrm{CO}^{-}$groups particularly depended on the $\mathrm{pH}$. The application of the model also permitted the assessment of the bioavailability of the studied elements by stating e.g. that lead carbonate $\left(\mathrm{PbCO}_{3}\right)$ occurring in the analysed samples showed no tendency for dissociation to free $\mathrm{Pb}^{2+}$ forms. The obtained data also suggest that the complexation of ions particularly depended on the content of anionic forms in the samples, and on the $\mathrm{pH}$ values.

Bäckström et al. (2003) analysed the total content, content of particular fractions, and performed modelling (with the application of the PHREEQC-2 software) for elements such as $\mathrm{Cd}, \mathrm{Co}, \mathrm{Cu}, \mathrm{Pb}$, and $\mathrm{Zn}$ present in sewage from roads and streets. The obtained results permitted the assessment of the possibility of transport of the studied elements towards the nearby fields with surface runoff. The application of the model enabled the assessment of the effect of organic complexating compounds on the availability and binding of heavy metals in the analysed samples (Bäckström et al. 2003; Fest et al. 2008). Moreover, the calculations obtained due to the application of the PHREEQC-2 model permitted the interpretation of the results of speciation analysis conducted by the traditional method, only allowing for the determination of the fractions of a given elements, but not the identification of its forms.

Computer simulations constitute an important tool for speciation of radionuclides such as uranium, thorium, ruthenium, iodine, and technetium in environmental samples (Harvey and Leonard 2002). Com- puter programs are also effectively used in the analysis of biological samples. Harris et al. (2012) applied the ECCLES software for modelling the binding and movement of $\mathrm{Fe}^{3+}, \mathrm{Fe}^{2+}, \mathrm{Cu}^{2+}, \mathrm{Zn}^{2+}$, and $\mathrm{Mn}^{2+}$ in bast. According to the calculations, the analysed metals mainly occurred in bast in the forms of chelates, and the contribution of free ions was insignificant.

Results of research concerning speciation conducted with the application of various computer programs and by means of experimental methods usually show high conformity. This suggests the usefulness and justification of the application of digital methods for the determination of the mobility and bioavailability of metals in environmental samples (Fotovat and Naidu 1997; McGrath et al. 1986; Holm et al. 1995; Stephan et al. 2008). Due to the specificity of research methods based on calculations, however, like in the case of the speciation study, the obtained results are difficult to verify. In speciation analyses, the assessment of the credibility of the effect of modelling performed based on selected data is of high importance. Too low concentrations of heavy metals in solutions or lack of possibilities of the experimental determination of the speciation forms of a given metal may be problematic. Models and computer programs should be verified and improved based on the experimental data obtained from traditional speciation analyses. (Stephan et al. 2008). Models and software can also be used to verify traditional speciation methods.

\section{CONCLUDING REMARKS}

The total content and forms of occurrence of elements in soils depend on the changing conditions and physical and chemical parameters. Geochemical models applied in computer programs are a useful tool for predicting the effect of changes in the environment on the distribution, mobility, and bioavailability of heavy metals in soils and other components of the environment. They can be effectively applied for predicting the release of heavy metals e.g. from waste dumps. The condition of conducting speciation analyses in environmental laboratories by means of digital methods is the application of specialised computer software. According to many authors, a great challenge in the scope of speciation analysis is the development of high quality data bases based on which modelling reflecting the actual natural conditions can be performed. Obtaining more detailed and credible results in soil and agricultural sciences requires the implementation and application of computer programs, modelling, and simulation. Researchers as well as legislators in the scope of environmental protection 
and soil sciences should be aware of the need of changes in national provisions regarding the content of heavy metals in soils (Mohammed 2012; Zhang et al. 2008; Bonazountas 1986), and consideration in such provisions of forms or fractions of heavy metals. This would permit the development of a data base which, supported by computer risk assessment methods, would provide the basis for the determination of heavy metals' mobility or potential toxicity.

\section{REFERENCES}

Allison J.D., Brown D.S., Novo-Gradac K.J., 1999. MINTEQA2/ PRODEFA2, a geochemical assessment model for environmental systems: Version 4.0. U.S. Environmental Protection Agency National Exposure Research Laboratory Ecosystems Research Division Athens, Georgia: 75 pp.

Bäckström M., Nilsson U., Häkansson K., Allard B., Karlosson S., 2003. Speciation of heavy metals in road runoff and roadside total deposition. Water, Air, Soil Pollution 147: 343-366.

Bonazountas M., 1986. Chemical Fate Modelling in Soil Systems: A State-of-the-Art Review. Commission of the European Communities, Scientific Basis for Soil Protection in the European Community (Barth H., Hermite P.L., Eds.) Elsevier, Applied Science: 487-566.

Cabaniss S.E., 1987. TITRATOR: An interactive program for aquatic equilibrium calculations. Environmental Science and Technology 21: 209-210.

Cederberg G.A., Street R.L., Leckie J.O., 1985. A groundwater mass transport and equilibrium chemistry model for multicomponent systems. Water Resources 21: 1095-1104.

Crawford M.B., 1996. PHREEQEV: the incorporation of a version of model $\mathrm{V}$ for organic complexation in aqueous solutions into the speciation code PHREEQE. Computers \& Geosciences 22(2): 109-116.

Davis J.A., Kent D.B., 1990. Surface complexation modeling in aqueous geochemistry. Review Mineralogy 23: 177-260.

Dzombak D.A., Morel F.M.M., 1990. Surface Complexation Modelling: Hydrous Ferric Oxide, John Wiley and Sons, New York: 5-6.

Erten-Unal M., Wixon B.G., 1999. Biotreatment and chemical speciation of lead and zinc mine/mill wastewater discharges in Missouri, U.S.A. Water, Air and Soil Pollution 116: 501-522.

Falc W.E., 1991. Multisite binding equilibria and speciation codes, incorporation of the electrostatic interaction approach in to PHREEQE, Computers and Geosciences 17: 1219-1234.

Fardy J.J., Sylva R.N., 1978. SIAS, A computer program for the generalized calculation of speciation in mixed metal ligand aqueous systems. Australian Atomic Energy Commission, Rep. No. AAEC/E445.

Fest E.P.M.J., Temminghoff E.J.M., Comans R.N.J., Riemsdijk W.H., 2008. Partitioning of organic matter and heavy metals in a sandy soil: Effects of extracting solution, solid to liquid ratio and $\mathrm{pH}$. Geoderma 146: 66-74.

Fotovat A., Naidu R., 1997. Ion exchange resin and MINTEQA2 speciation of $\mathrm{Zn}$ and $\mathrm{Cu}$ in alkaline sodic and sodic extracts. Australian Journal of Soil Research 35: 711-726.

Goldberg S., Corwin D.L., Shouse P.J., Suarez D.L., 2005. Prediction of Boron Adsorption by Field Samples of Diverse Textures. Soil Science Society of America Journal 69: 1379-1388.
Harris W.R., Sammons R.D., Grabiak R.C., 2012. A specification model of essential trace metal ions in phloem. Journal of Inorganic Biochemistry 116: 140-150.

Harvey B.R., Leonard K.S., 2002. Speciation of radionuclides, Chemical speciation in the Environment. Blackwell Science: 358-386.

Holm P.E., Christensen T.H., Tjell J.C., McGrath S.P., 1995. Heavy metals in the environment. Speciation of cadmium and zinc with application to soil solutions. Journal of Environmental Quality 24: 183-190.

Jóźwiak K., 2013. Konstrukcja i typowe uproszczenia w modelu geochemicznym na przykładzie programu Phreeqc, Przegląd Geologiczny (Geological Quarterly) 61(1): 54-61.

Keizer M.G., 1991. ECOSAT: A computer Program for the calculation of speciation in soil-water systems. Department of Soil Science and Plant Nutrition, Agricultural University Wageningen, The Netherlands.

Kowalkowski T., Buszewski B., 1999. Modelowanie i symulacja jako podstawowy obszar badań chemometrycznych w chemii środowiska. Chemia i Inżynieria Ekologiczna (Ecological Chemistry and Engineering) 6(11): 1121-1130.

Lumsdon D.G., Evans L.J., 2002. Predicting chemical speciation and computer simulation. Chemical Speciation in the Environment-second edition, Blackwell Science: 89-131.

Mattigod S.V., Sposito G., 1979. Chemical modeling of trace metal equilibria in contaminated soil solutions using the computer program GEOCHEM. (Jenne E.A editor) Chemical modeling in aqueous systems. ACS symposium series no. 93. American Chemical Society, Washington: 837-856.

McGrath S.P., Sanders J.R., Laurie S.H., Tancok N.P., 1986. Experimental determinations and computer predictions of trace metal ion concentrations in dilute complex solutions. Analyst 111: 459-465.

Mohammed S.A.S., 2012. Studies on surface complexation modeling of $\mathrm{Zn}$ on soil and soil mixtures as a proposed liner material for waste containment facilities. Journal of Materials and Environmental Science 3(6): 1117-1122.

Morel F.M., Morgan J.J., 1972. A numerical method for computing equilibria in aqueous chemical systems. Environmental Science and Technology 6: 58-67.

Ołpiński M., Trela B., Warchoł J., 2011. Usuwanie metali ciężkich na sorbentach modyfikowanych EDTA i DTPA. Zeszyty Naukowe Politechniki Rzeszowskiej, Budownictwo i Inżynieria Środowiska. (Journal of Civil Engineering, Environment and Architecture) 58(2): 237-255.

Papelis C., Hayes K.F., Leckie J.O., 1998. HYDRAQL: A program for the computation of chemical equilibrium composition of aqueous batch systems including surface-complexation modeling of ion adsorption at teh oxide/solution interface. Technical Report 306, Stanford University Department of the Civil Engineering, Stanford: 130 pp.

Perrin D.D., Sayce I.G., 1967. Computer calculations of equilibrium concentrations in mixtures of metal ions and complexing species. Talanta 14: 833-842.

Pizzol M., Bulle C., Thomsen M., 2012. Indirect human exposure assessment of airborne lead deposited on soil via a simplified fate and speciation modelling approach. Science of the Total Environment 421/422: 203-209.

Rastmanesh F., Moore F., Keshavarzi B., 2010. Speciation and phytoavailability of heavy metals in contaminated soils in Sarchesmeh Area, Kerman Province, Iran. Bulletin of Environmental Contamination and Toxicology 85: 515-519. 
Rathnayake I.V.N., Megharaj M., Krishnamurti G.S.R., Nanthi B.S., Naidu R., 2013. Heavy metal toxicity to bacteria - Are the existing growth media accurate enough to determine heavy metal toxicity? Chemosphere 90: 1195-1200.

Rogan N., Dolenec T., Serafimovski T., Tasev G., Dolenec M., 2008. Determination of heavy metals in paddy soils (Kočani Field Macedonia) by a sequential extraction procedure. Materials and Geoenvironment 55(4): 444-455.

Rutkowska B., Szulc W., Bomze K., 2013. Effects of the soil properties on copper speciation in soil solution. Journal of Elementology 18(4): 695-703.

Sahai N., Sverjensky D.A., 1998. GEOSURF: A computer program for modeling adsorption on mineral surfaces from aqueous solution. Computers and Geoscience 24(9): 853-873.

Smal H., 1999. Właściwości chemiczne roztworów glebowych gleb lekkich i ich zmiany pod wpływem zakwaszenia. Rozprawy Naukowe Akademii Rolniczej w Lublinie, 230: 180 pp.

Sposito G., Coves J., 1988. SOILCHEM, A computer program for the calculation of chemical speciation in soils. The Kearny Foundation of soil science, University of California, CA.

Sposito G., Bingham F.T., Yadav S.S., Inouye C.A., 1983. Trace metal complexation by fulvic acid extracted for sewage sludge: II. Development of chemical models. Soil Science Society of America Journal 46: 51-56.

Sposito G., Mattigod S.V., 1980. GEOCHEM: A computer program for the calculation of chemical equilibria in soil solu- tions and other natural water systems. Kearney Foundation of Soil Science, University of California, Riverside.

Stephan C.H., Courchesne F., Hendershot W.H., McGrath S.P., Chaudri A.M., Sappin-Didier V., Sauve S., 2008. Speciation of zinc in contaminated soils. Environmental Pollution 155(2): 208-216.

Vithanage M., UpamaliR.A., Dou X., Bolan N. S., Yang J.E., Sik Ok Y., 2013. Surface complexation modeling and spectroscopic evidence of antimony adsorption on iron-oxide-rich red earth soils. Journal of Colloid and Interface Science 406: 217-224.

Wesley R., Harris R., Sammons D., Grabiak R.C., 2012. A speciation model of essential trace metal ions in phloem. Journal of Inorganic Biochemistry 116: 140-150.

Winid B., 2013. Badania specjacji bromu w wodach o zróżnicowanym zasoleniu na podstawie modelowania geochemicznego. Rocznik Ochrona Środowiska. (Annual Set The Environment Protection) 15: 2452-2467.

Zachara J.M., Aninsworth C.C., Cowan C.E, Resch C.T., 1989. Adsorption of chromate by surface soil horizons. Soil Science Society of America Journal 53: 418-428.

Zhang Y., Jiang J., Chen M., 2008. MINTEQ modeling for evaluating the leaching behavior of heavy metals in MSWI fly ash. Journal of Environmental Sciences 20: 1398-1402.

Received: March 19, 2014

Accepted: June 30,2014

\section{Wykorzystanie zaawansowanych programów komputerowych do specjacji metali ciężkich $w$ glebach $i$ innych próbkach środowiskowych}

Streszczenie: W pracy przedstawiono, wiele stosowanych z powodzeniem na całym świecie, komputerowych programów do specjacji metali ciężkich w próbkach środowiskowych. Programy te mogą być stosowane w ocenie mobilności, toksyczności, biodostępności metali ciężkich lub podatności zanieczyszczeń na biodegradację. W pracy podano przykłady, zastosowanie oraz interpretację wyników specjacji metali ciężkich w próbkach środowiskowych. Ideą zastosowania takich programów jest otrzymanie modelu specjacyjnego, który pozwala na określenie (teoretyczne) w jakich formach występuje dany pierwiastek w badanej próbce środowiskowej (gleba, woda, osad) co jest niezwykle istotne ze środowiskowego punktu widzenia. Efekt końcowy zależy od wyboru odpowiednich, rzeczywistych danych wejściowych i zastosowania ich w modelu. Wyniki służą do przewidywania losu i zachowania pierwiastków w środowisku, ale także mogą być wykorzystane w tworzeniu, np. krzywych rozpuszczalności.

Stowa kluczowe: specjacja, programy komputerowe, modelowanie, metale ciężkie 